PACS: 62.20.Dc

UDC: 539.3

\title{
Electroosmotic pressure in the process of a biocompatible coating applying on the inner surfaces of nanostructured ceramics
}

\author{
Yu.I. Boyko, V.V. Bogdanov, R.V. Vovk, V.F.Korshak \\ V.N. Karazin Kharkiv National University, 4 Svoboda sq., Kharkiv, 61022, Ukraine \\ rvvovk2017@gmail.com
}

ORCID: 0000-0002-9008-6252

DOI:10.26565/2222-5617-2019-31-05

The role of the effect of electroosmosis in the process of electrochemical deposition of a biocompatible coating on the inner surfaces of porous nanostructured ceramics, a material used to make endoprostheses and implants in medicine, is discussed.

The biocompatibility of endoprostheses and implants with the human body is ensured by applying a special coating on the internal and external surfaces of the base material. The commonly acepted chemical compound used to form this coating is hydroxyapatite $\mathrm{Ca}_{10}\left(\mathrm{PO}_{4}\right)_{6}(\mathrm{OH})_{2}$. Multicomponent ceramic materials, from which the basis of endoprostheses and implants are made, are usually obtained by the traditional method of powder metallurgy - sintering, i.e., exposure of a mixture of powders at an elevated temperature under pressure. The material obtained in this way is a polycrystal. In addition, the structure of such a material contains a certain amount of voids in the form of individual pores or their associations (capillaries).

The paper shows that the use of nano-structured ceramic materials with a characteristic average size of structural elements (grains, pores and their aggregations) of the order $\approx\left(10^{-9}-10^{-7}\right) \mathrm{M}$ as a material for the manufacture of implants may determine the greater efficiency of the process of electrochemical application of a biocompatible coating on them, since the resulting large electroosmotic pressure in the capillaries leads to a greater degree of filling of the porous system with electrolyte.

The magnitude of the electroosmotic pressure can be increased by increasing the strength of the acting electric field or by decreasing the dielectric constant of the electrolyte $\varepsilon$ when additional chemical additives are introduced into the electrolyte.

The maximum degree of hollow channels (capillaries) filling with electrolyte, and, consequently, the efficiency of applying a biocompatible coating to the internal surfaces of ceramics using the electrochemical method, is achieved with the capillary system of the material being completely open.

Keywords: Sintering of powder compacts, nano-structured materials, biocompatible coating, electro-osmotic pressure.

\section{Електроосмотичний тиск у процесі нанесення біосумісного покриття на внутрішні поверхні наноструктурованої кераміки Ю.І. Бойко, В.В. Богданов, Р.В. Вовк, В.Ф.Коршак \\ Харківський національний університет імені В.Н. Каразіна, м. Свободи 4, 61022, Харків, Украӥна}

Обговорюється роль ефекту електроосмосу в процесі електро-хімічного нанесення біосумісного покриття на внутрішні поверхні пористої нано-структурованої кераміки - матеріалу, що використовується для виготовлення ендопротезів і імплантів в медицині.

Біосумісність ендопротезів і імплантів з людським тілом забезпечується нанесенням спеціального покриття на внутрішні та зовнішні поверхні матеріалу-основи. Загальновизнаною хімічною сполукою, що використовується для формування зазначеного покриття, є гідроксиапатит $\mathrm{Ca}_{10}\left(\mathrm{PO}_{4}\right)_{6}(\mathrm{OH})_{2}$. Полікомпонентні керамічні матеріали, 3 яких виготовляють основу ендопротезів і імплантів, зазвичай отримують традиційним методом порошкової металургії спіканням, тобто витримкою суміші порошків при підвищеній температурі в умовах дії всебічного тиску. Отриманий у такий спосіб матеріал, $є$ полікристалом. Окрім цього, в структурі такого матеріалу $є$ певна кількість пустот у вигляді окремих пор або їх об'єднань (капілярів).

В роботі показано, що використання як матеріала для виготовлення імплантів нано-структурованих керамічних матеріалів з характерним середнім розміром структурних елементів (зерен, пор та їх скупчень) порядку $\approx\left(10^{-9}-10^{-7}\right)$ м може зумовити більшу ефективність процесу електрохімічного нанесення біосумісного покриття на них, оскільки великий електроосмотіческій тиск, що виникає в капілярах, призводить до більшого ступеня заповнення пористої системи електролітом.

Величину електроосмотичного тиску можна збільшити шляхом підвищення напруженості діючого електричного поля або шляхом зменшення значення діелектричної проникності електроліту $\varepsilon$ при введенні в електроліт додаткових хімічних добавок.

Максимальний ступінь заповнення порожніх каналів (капілярів) електролітом, a, отже, і ефективність нанесення біосумісного покриття на внутрішні поверхні кераміки при використанні електрохімічного методу, досягається при повній відкритості капілярної системи матеріалу.

Ключові слова: Спікання порошкових прессовок, нано-структуровані матеріали, нанесення біосумісного покриття, електро-осмотичний тиск.

(C) Boyko Yu.I., Bogdanov V.V., Vovk R.V., Korshak V.F., 2019 


\title{
Электроосмотическое давление в процессе нанесения
}

\author{
биосовместимого покрытия на внутренние поверхности \\ наноструктурированной керамики \\ Ю.И. Бойко, В.В. Богданов, Р.В. Вовк, В.Ф.Коршак \\ Харьковский национальныцй университет имени В.Н. Каразина, м. Свободы 4, 61022, Харьков, Украина
}

\begin{abstract}
Обсуждается роль эффекта электроосмоса в процессе электро-химического нанесения биосовместимого покрытия на внутренние поверхности пористой нано-структурированной керамики - материала, использующегося для изготовления эндопротезов и имплантов в медицине.

Биосовместимость эндопротезов и имплантов с человеческим телом обеспечивается путем нанесения специального покрытия на внутренние и внешние поверхности материала-основы. Общепризнанным химическим соединением, использующимся для формирования указанного покрытия, является гидроксиапатит $\mathrm{Ca}_{10}\left(\mathrm{PO}_{4}\right)_{6}(\mathrm{OH})_{2}$. Поликомпонентные керамические материалы, из которых изготавливают основу эндопротезов и имплантов, обычно получают традиционным методом порошковой металлургии - спеканием, т. е. выдержкой смеси порошков при повышенной температуре в условиях действия всестороннего давления. Полученный таким способом материал, является поликристаллом. Кроме этого, в структуре такого материала содержится определенное количество пустот в виде отдельных пор или их объединений (капилляров).

В работе показано, что использование в качестве материала для изготовления имплантов нано-структурированных керамических материалов с характерным средним размером структурных элементов (зерен, пор и их скоплений) порядка $\approx\left(10^{-9}-10^{-7}\right)$ м может обусловить бо́льшую эффективность процесса электрохимического нанесения биосовместимого покрытия на них, поскольку возникающее большое электроосмотическое давление в капиллярах приводит к бо́льшей степени заполнения пористой системы электролитом.

Величину электроосмотического давления можно увеличить путем повышения напряженности действующего электрического поля или путем уменьшения значения диэлектрической проницаемости электролита $\varepsilon$ при введении в электролит дополнительных химических добавок.

Максимальная степень заполнения полых каналов (капилляров) электролитом, а, следовательно, и эффективность нанесения биосовместимого покрытия на внутренние поверхности керамики при использовании электрохимического метода, достигается при полной открытости капиллярной системы материала.
\end{abstract}

Ключевые слова: Спекание порошковых прессовок, нано-структурированные материалы, нанесение биосовместимого покрытия, электро-осмотическое давление.

\section{Introduction}

One of the important areas of modern materials science is the synthesis of mechanically durable and wearresistant materials having biocompatibility with the human body (bone and fabric). The relevance of obtaining such materials and of their physical, chemical and biological properties study are due to the vital need for producting for medical purposes of orthopedic endoprostheses and various implants [1-5]. As the main material in the making of such products traditionally used metals $\mathrm{Ti}, \mathrm{Ni}$ or their alloys [6]. However, in recent years, the possibility of using for this purpose other materials, in particular, various multicomponent ceramics, has been actively studied. Such materials include, for example, ceramics based on the so-called MAX phases; ceramics made of refractory oxides $\mathrm{Al}_{2} \mathrm{O}_{3}, \mathrm{Y}_{2} \mathrm{O}_{3}$ (oxide ceramics); "Amorphous" ceramics ( $\mathrm{Si}, \mathrm{B}, \mathrm{N}, \mathrm{C}$ ), obtained by polycondensation [7] and others. Biocompatibility of endoprostheses and implants with the human body provided by applying a special coating on the inner and outer surfaces of the base material. The generally accepted chemical compound used to form this coating is hydroxyapatite $\mathrm{Ca}_{10}\left(\mathrm{PO}_{4}\right)_{6}(\mathrm{OH})_{2}$ [3-6].

The multicomponent ceramic materials of which are made the basis endoprostheses and implants are usually obtained by traditional powder metallurgy method - sintering, i.e. by exposure of powder mixture at elevated temperature under the action of hydrostatic pressure [8]. The material obtained in this way is a polycrystal. In addition, the structure of such material contains a certain amount of voids in the form of individual pores or their associations (capillaries). At sufficient value of porosity of the material $\geq 30 \%$, the capillaries, intersecting with each others, form a whole network of cavities that penetrate through it, i.e. open porosity is formed. In essence, such ceramic material is a specific membrane through which the liquid can penetrate through the hollow channels.

In recent years for the synthesis of ceramics began to use other methods that differ from the traditional method of the high-temperature sintering of powders under pressure. A distinctive feature of these methods is a short exposure time at elevated temperatures: sintering in the plasma discharge, sintering by passing high-current shortduration pulses of electric current (method of electroconsolidation), sintering by the method of pulsed heating and cooling etc. [9,10]. Herewith, powders with an average size of $\approx\left(10^{-9}-10^{-7}\right) \mathrm{m}$ (nano-sized powders) are used as the initial material for sintering by the listed methods. As a result of using these sintering methods, socalled nano-structured ceramics is obtained - material with average size of structural elements (grains, pores and 
their clusters), which coincides with the average size of the initial powders.

Material with such a small size of structural elements is characterized by special mechanical properties. In particular, such a material has a high plasticity, which is a very important factor for the process of endoprostheses and implants producting from these materials, since these products usually have a complicated geometric shape.

The heightened plasticity of nano-structured ceramics is due to the fact that the main mechanism limiting the rate of material transport during deformation is not a classical dislocation mechanism, but a more efficient and energetically facilitated mechanism of grain-boundary sliding (Ashby-Ferral mechanism) [11]. In this case, the rate of plastic deformation is determined by the point defects reactions (by the generation and annihilation of vacancies) as the dislocations slip directly at the grain boundaries. The effectiveness of this material transport mechanism is due to the movement of grains as a whole in distinction to conventional coarse polycrystals, in which the rate of plastic deformation is controlled by the movement of dislocations or of their clusters in the volume of grains.

It should be noted that in addition to the increased plasticity of the ceramic material synthesized from nanopowders, this material is also characterized by high crack resistance. This is due to the fact that the grain boundary network development is a factor contributing to blocking of the formation of main cracks leading to the material destruction [12].

In addition to the special mechanical properties of nano-structured ceramics, the presence in it of a developed grid of nano-sized hollow channels (capillaries) is also a factor determining the preferential use of the material as compared to conventional microstructured ceramics in the production of prostheses and implants. Indeed, the biocompatibility of the material used for these purposes is provided for coating the hydroxylapatite layer on its external and internal surfaces. In the case of nano-structured ceramics, hollow capillaries significantly increase its total internal surface compared to conventional coarse grained ceramic materials. This fact, as well as the very small average size of the capillaries cross-section, can significantly contribute to improving the quality of the applied hydroxyapatite layer. Let's ground this assumption.

One of the well-known and widely used methods of applying a coating of hydroxyapatite, is the method of electro-chemical deposition [13]. It lies in the fact that the original ceramic material is placed in an aqueous solution prepared from a mixture of compounds $\mathrm{Ca}\left(\mathrm{NO}_{3}\right)_{2}$ and $\mathrm{NH}_{4} \mathrm{H}_{2} \mathrm{PO}_{4}$. In fact, this solution is a liquid mixture of ions with opposite electric charges (electrolyte). Formation of the coating occurs under the action of a constant electric field at a voltage on the electrodes of a few volts and exposure for some time. To maintain of a homogeneous distribution of ions $\mathrm{Ca}^{2+}$ and $\left(\mathrm{H}_{2} \mathrm{PO}_{4}\right)^{2-}$ used solution is mechanically mixed. At the final stage the samples are dried at the temperature of $\approx 100^{\circ} \mathrm{C}$ what ultimately leads to the formation of an amorphous or crystalline hydroxyapatite layer on the inner and outer surfaces of the base material sample. Obviously, in the process of implementing the above-described method of applying a coating on the internal surfaces of porous ceramics, conditions arise for development of the socalled electrokinetic effects, in particular, of the electroosmosis effect [14]. This effect is due to the interaction of an external electric field with the double charged layer of thickness $\delta \approx 10^{-9} \mathrm{~m}$, formed at the interface of the liquid electrolyte and the solid phase. The electric field directed along the boundary interface causes the liquid flow relative to the solid phase with a velocity $\mathrm{v}$. It is this effect is directly related to the process of a biocompatible coating applying on the internal surface of the ceramic material. In this case, the most interesting is the nano-structured porous material., i.e. the material containing a network of hollow channels (capillaries), the radius of which has the value of $\mathrm{r} \approx\left(10^{-8}-10^{-7}\right) \mathrm{m}$ and a network of crystal grains of the same size.

This paper is devoted to the consideration just of the electroosmosis effect role when using the electrochemical method of a biocompatible coating applying on the internal surfaces of porous nano-structured ceramics.

\section{Electroosmotic pressure in porous nano-structured ceramics}

The To simplify the analysis, all the consideration will be applied to a defect in the form of a hollow channel (capillary), having the shape of a cylinder of radius $r$, penetrating through the ceramic sample, placed in the liquid phase (electrolyte). We also suppose that a constant electric field of strength $\mathrm{E}$ acting along the axis of the capillary. The applied electric field, as already mentioned, causes the liquid to move relative to the capillary walls (electroosmotic effect). The direction of liquid flow is determined empirically by the rule, according to which a phase with a higher dielectric constant is characterized by an excess positive electric charge compared to another (neighboring) phase, which is negatively charged. This effect has been studied theoretically and experimentally and has been described in many papers (see, for example, [14-16]). Herewith, the studies carried out were done with materials containing capillaries, the radius of which $\mathrm{r}_{0}$ was characterized by the size range of $\approx\left(10^{-6}-10^{-5}\right) \mathrm{m}$ (micrometric systems).

According to the theory of electroosmosis, the movement of the electrolyte in the hollow capillary under the influence of the electric field occurs until the force 
acting from the electric field is balanced by the friction force, which is determined by the viscosity of the liquid and by the liquid flow velocity gradient, directed perpendicular to the velocity vector. At steady state, the hydrodynamic flow of electrolyte, caused by the action of an electric field, is balanced by the liquid flow in the opposite direction, due to the emerging of the so-called electroosmotic pressure $\mathrm{P}_{\mathrm{e}}$.

Essentially, the $\mathrm{P}_{\mathrm{e}}$ value characterizes the maximum possible degree of the capillary filling with electrolyte. The equation connecting the magnitude of the electroosmotic pressure $\mathrm{P}_{\mathrm{e}}$ with the geometric parameters of the capillary and the voltage $U$ is [14]

$$
\mathrm{P}_{\mathrm{e}}=8 \mathrm{U} \sigma \delta / \mathrm{r}^{2}
$$

Here $\sigma$ is the surface density of the electric charge directly at the "solid phase - electrolyte" interface, $\delta$ is the thickness of the double electric layer formed in the electrolyte, $r$ is the radius of the capillary.

From relation (1) it follows that the magnitude of the electroosmotic pressure $\mathrm{P}_{\mathrm{e}}$, which determines the maximum possible degree of the capillary filling with electrolyte (on reaching of the stationary state), significantly depends on the capillary radius $r_{0}$. Note that in such a record the value of $\mathrm{P}_{\mathrm{e}}$ does not depend on the capillary length, which allows using (1) to describe the filling with liquid electrolyte not only of a single capillary, but also of a capillary system, i.e. of the porous material (membrane) as a whole.

From (1) it follows that by ceteris paribus, a decrease in the radius of capillaries from the value $\approx 10^{-6} \mathrm{~m}$ (micrometric system) to $\approx 10^{-8} \mathrm{~m}$ (nano-sized system) can lead to an increase in electroosmotic pressure by $\approx 10^{4}$ times. Thus, the use of nano-structured porous material can lead to greater efficiency of the process of electrochemical deposition of a biocompatible coating during the production of endoprostheses and implants, since the higher value of electroosmotic pressure corresponds to the higher degree of filling of the porous system with electrolyte. At the same time, it should be emphasized that the conclusion made is valid only when the required condition of the electroosmotic pressure theory is fulfilled: $r>>\delta$.

In the case when the radius of the capillaries reaches the thickness of the double charged layer, i.e. $r \geq \delta \approx 10^{-9} \mathrm{~m}$, the physical description of the discussed effect is completely changed. [18]. In addition, it should have in mind that the estimated change in the value of electroosmotic pressure during the transition from microto nano-structured ceramics has a maximum value. In real conditions in equation (1) it is necessary to take into account an additional coefficient (factor) characterizing the degree of capillary openness. Quantitatively, this coefficient $\chi \leq 1$ is a complex function of the material porosity. As a rule, its value is measured experimentally.

\section{Conclusions}

The above discussion suggests that nano-structured ceramic materials are characterized by the much higher electroosmotic pressure $\mathrm{P}_{\mathrm{e}}$ compared to micro-sized ceramics. The increased value of electroosmotic pressure contributes to a greater degree of filling of the internal surfaces of ceramics with electrolyte.

The maximum degree of hollow channels (capillaries) filling with electrolyte, and, consequently, the effectiveness of biocompatible coating applying on the inner ceramic surfaces using the electrochemical method achieved with full openness of the capillary system of the material.

For crystallization of hydroxyapatite from a liquid solution (electrolyte) in the pores of the ceramic material at the final stage of coating, it is necessary to carry through heat treatment (drying). The temperature and time of heat treatment must be selected experimentally.

\section{References}

1. C W. Barsoum, Prog. Solid St. Chem., 28, 201 (2000).

2. I. Salama, T. El- Raghly, W. Barsoum, Journ. of Alloys and Comp., 347, 1-2, 271 (2002).

3. A. A. Smetkin, Yu. K. Majorova, Vestnik PNIPU, 17, 120 (2015).

4. M. A. Hadi, R. V. Vovk, A. Chroneos, J. Mater. Science: Mater. Elektron., 27, 11925 (2016).

5. M. A. Hadi, M. Roknuzzaman, A. Chroneos, S. H. Naqib, A. K. Islam, R. V. Vovk,

6. K. Ostrikov, Comput. Mater. Science, 137, 318 (2017).

7. J. Katic, M. Metikos - Hukovic, R. Babic, J. Appl. Electrochem., 44, 87 (2014).

8. Ju. I. Boyko, Vestnik HNU, Physic, 15, 54 (2011).

9. V. Skorohod, S. M. Solonin, Metall. Sintering, Moskow, (1984).

10. P. V. Istomin, A. V. Nadutkin, Ju. I. Riabkov, B. A Goldin, Neorg. Materials, 42, 292 (2006).

11. R. V. Vovk, N. M. Prokopiv,V. A. Chishkala, M. V. Kislitsa, Functional Materials, 25, 43 (2018).

12. M. Ashby, R. Verral, Acta Metall, 21, 149 (1973).

13. V. M. Finkel, Fizika razrusheniya, Moskva, Metallurgiya (1970).

14. X. Lin, K, Groot, D. Wang, Q. Hu, D. Wismeijer, Y. Liu, The Open Biomedical Engineering Journal, 9, 56 (2015).

15. M. Smoluchowski, Handbuch der Electrizitat and Magnetismus, 2, Leipzig (1959).

16. J. Newman, Elektrohimicheskiye sistemy, «Mir», Moskva (1977).

17. L. I. Antropov, Teoreticheskaya elektrohimiya, «Vyshaya shkola», Moskva (1975).

18. Ya. I. Frenkel, Kineticheskaya teoriya zhidkostej, Leningrad, «Nauka» (1975).

19. Ju. I. Boyko, Vestnik HNU, Physics, 18, 20 (2013). 